\title{
Introduction: intergenerational relations in families - a micro-macro perspective
}

\section{Chiara Saraceno}

\section{PREMISE}

Intergenerational relations in society and in families are at the core of both continuity and change in the sense that successive generations and cohorts enter social and family systems that have been shaped by preceding generations, and then in their turn reshape them. Intergenerational relations in families are a crucial vehicle for the reproduction of norms and social values. They are also a crucial vehicle for the reproduction of social stratification. Thus, intergenerational relationships should be an important focus of sociological analysis, bridging the micro level of family interactions with the meso and macro levels of social institutions and change.

Intergenerational relationships in families have gained the attention of European sociology research only relatively recently, notwithstanding pioneering studies, such as those of Willmott and Young (1964) in the UK and Agnes Pitrou (1977) in France, that showed the importance of kinship ties. Interest in intergenerational relationships as such developed earlier and more systematically in the US, where the focus on the experience of the elderly offered a critical and contrasting view of the family to that shaped by the Parsonsian vision of the isolated nuclear family (e.g., Sussman and Burchinal 1962). As early as 1993, Bengtson and Achenbaum's important compiled volume mapped out some of the most salient issues posed by

ageing societies with regard to intergenerational relations in families and societies. $^{1}$

For the past two decades, European research has been catching up, however, and from a very early stage has adopted a comparative perspective. This has been accompanied by the development of comparative databases, such as the EU-funded OASIS, SHARE and KASS programmes, and the Gender and Generation programme financed by the United Nations Commission for Europe (UNECE). In fact, the existence within Europe of both a variety of longstanding 'kinship regimes' (see Reher 1998) and of distinctive welfare regimes raises the issue as to how these are 
affected by population and kinship ageing and, vice versa, how different kinship regimes and types of welfare state shape the cultural, normative and practical context in which intergenerational relationships take place. Welfare states can, in fact, be understood in part as a kind of social contract between social generations that runs parallel to the intergenerational contracts within families and kin. Actually, welfare state policies are to a large degree not only policies of age and of obligations between social generations, for example, through the pension and the school systems. They are also forms of regulating obligations within family generations, through measures concerning maternity and parental leaves, child benefits, access to education, to social assistance and social care, and through legal definitions of 'family obligation' (on this last aspect see, e.g., Millar and Warman 1996). They therefore frame the context in which intergenerational relations are embedded. Conversely, country-specific cultural expectations concerning intergenerational obligations within families may act as an incentive or, on the contrary, a disincentive to the development of specific forms of welfare arrangements - or indeed may act as a buffer when these are lacking. Both of these kinds of contracts - the social and the family differ across European countries.

The link between (both emotional and practical) intergenerational contracts in the family and in society is bi-univocal and is also strongly embedded in ideas of family and conceptions of citizenship. These influence each other reciprocally and are far from static. Moreover, the two forces - in addition to globalisation and changing balances in world economies - that have impacted most on welfare states and specifically on the conditions of their implicit (social) intergenerational contracts, namely population ageing and the increase in women's labour force participation, also impact on family intergenerational contracts. Women's labour force participation, in fact, affects the implicit gender contract that supports both the social division of labour between families and society and the family division of labour between earning and caring. It has an impact on fertility and on the availability of family caregivers at a time when increased life expectancy is also bringing about an increase in the number of frail elderly people requiring care. And population ageing not only affects the age structure and the interaction of age groups within societies, but also reshapes relations and generational positions within families and kin, rendering the intergenerational structure of families more complex: more generations are living for longer periods within the same time span and more generational roles are available over the life course and even simultaneously (in the sense that one can simultaneously be, for example, a daughter, a mother and a grandmother); each generational role is lasting longer than ever before. At the same time, something similar to what happens to the age structure of pop- 
ulations is also occurring in the generational structure of families and kinship networks. Fewer people now occupy the same generational positions at the bottom, particularly those of young child, young parent, young sibling or cousin. Conversely, more people than ever before occupy the top generational positions, particularly that of grandparent. In 1900, the number of children in Western Europe aged 0 to 14 was about five times higher than the number of persons aged 60 and over. In 2000, there were over 1.5 times more elderly people than children (European Data Service 2007; Flora et al. 1987). A child is likely to grow up having more grandparents than siblings and cousins, while his/her grandparents' siblings may still all be alive.

Overall, vertical intergenerational relations are becoming more numerous than horizontal ones. Whether they are also becoming more important is open to research and discussion and is partly the subject matter of this book. Certainly, this important change in the human resources context of family relationships should not be overlooked when analysing changes in the family. As a matter of fact, it is a change which is just as important, but is even more generalised than the phenomena that are usually focused on when looking at changes in family patterns: marital instability, cohabitation replacing marriage, mothers' labour force participation. At the same time, this last group of changes interacts with the lengthening and increasing complexity of intergenerational relations. Separation and divorce may strengthen relationships with one parent and her family line, but weaken relationships with the other parent and his family line. Repartnering by parents may add another set of intergenerational relationships as well as half-siblings and step-siblings. Cohabitation instead of marriage may also weaken intergenerational ties, given that cohabitation is generally believed to be at higher risk of breakdown than marriage.

This verticalisation of family ties may be a crucial asset in ageing societies as a means of developing social cohesion and easing social change. It may also represent a counterbalancing element in what many analysts define as the issue of intergenerational (in-)equity in public patterns of redistribution. The jury is still out in the debate on intergenerational accounting at the societal and specifically welfare-state level (for contrasting evaluations, see, e.g., Binstock and Guadagno 2001; Brady 2004; Esping-Andersen and Sarasa 2002; Walker 1993). But this debate concerns only the public intergenerational contract, ignoring the private one that occurs between generations in families. As many studies - including those in this volume - show, redistribution of income and services within families follows a quite different pattern to that which observers assume occurs through the public contract - sometime compensating, sometime integrating it. Analysing intergenerational relations in families, therefore, helps to 
explain why intergenerational conflict - although it is the object of many political and economic debates - does not mobilise social generations and age groups as such at the societal level, not even in countries, such as Italy and the southern European countries in general (the so-called pensioners' welfare states; see, e.g., Ferrera 1996), where redistribution is more evidently heavily skewed towards the older cohorts than elsewhere. What Sarah Arber and Claudine Attias-Donfut (2000) have called 'the myth of generational conflict' (also see Achenbaum 2004; Alber and Kohler 2004) can be explained by the existence of a private contract between generations within families. Of course, balances between public and private contracts, and therefore also patterns of interdependence between generations within families, differ across countries, and this mainly depends on the functioning of the public contract.

The strength and relevance of intergenerational, vertical ties for individuals' quality of life and life opportunities for long life spans and at different stages of the life course may however crystallise social inequalities across generations (for a discussion see Attias-Donfut and Wolff 2000a; Künemund et al. 2005). The stronger vertical ties may also introduce new forms of social inequality. Young and adult children belonging to poor families have a smaller family capital to count on when entering into adulthood; working mothers of young children with no mother or mother-inlaw available to help out may find it more difficult than those who do have such support to manage the daily act of balancing work and family obligations. Childless, frail elderly people, or frail elderly people whose children have migrated and live far away or with whom they do not have a good relationship, may risk social isolation. Divorce may rupture more than a couple's relationship - its consequences may also spread to the generations who were not yet born when the divorce occurred. These differences and inequalities are idiosyncratic to some degree and depend on the biography of each individual and each family. They are, however, also partly socially shaped. In countries where the family is the only or main resource a young person can count on when entering into adulthood or an elderly person can depend on when he/she becomes frail, the impact on social inequality and on the adequacy of support may be greater than in societies where individual entitlement to support is less familialised. Regulations that in cases of break-ups favour one parent (usually the mother) over the other reinforce the risk - already present in the gender division of parenting labour - of weakening the father-child relationship well into adulthood.

In the following pages, I will briefly discuss these different issues, many of which are specifically addressed in the various chapters. 


\section{TALL AND LEAN: MULTIGENERATIONAL FAMILY PATTERNS}

Since the early 1990s, various authors have used the metaphor of the 'beanpole' family to point out that, due to the combination of rising life expectancy and low fertility, kinship networks in developed countries are becoming 'tall and lean'. Notwithstanding, in fact, the increasing nuclearisation of households and even the growth in one-person households, families, in the sense of close kinship irrespective of cohabitation, have become increasingly complex along generational lines. The divergent trends of nuclearisation of households and increasing complexity of families and kin are made more visible by increasing life expectancy. Bertram (2000) has offered an apt definition of this contemporary multigenerational family as a 'multigenerational-multilocal' family.

The timing and intensity of the phenomenon of the verticalisation and slimming of kinship differ substantially, however, across countries in the developed world, because they depend on the interplay between various factors, which in turn have a different history and timing in each country (Coleman 2005): when and to what degree life expectancy started to increase; when and to what degree, at what speed and for how long patterns of fertility started to decrease; age at marriage and age at first birth, and so forth. Italy, in this perspective, has long been considered a special case because its fertility rate started to drop later than in most Western developed countries, but then at a much faster rate and to unprecedented low levels. The ageing and slimming of the Italian kinship structure, therefore, has been more evident and drastic than elsewhere. ${ }^{2}$ However, given the historically comparatively high marriage age and age of the birth of one's first child in this country, the chances of becoming a great-grandmother (and even more so a great-grandfather), and therefore of being part of a four-generation family, are lower than, for instance, in Sweden. The Survey of Health, Ageing and Retirement in Europe (SHARE) - a study on the over-50s (Börsch-Supan et al. 2005) - found a quite varied distribution of three- and four-generation families in 11 European countries, as shown in Figure I.1 and it is more fully discussed by Gunhild Hagestad in her chapter. They are more common in Scandinavia and France than in Italy, Greece or Germany. Meaningful cross-country differences had also been found previously in an analysis of cross-sectional data from the International Social Survey Program (ISSP) covering five European countries (Austria, West Germany, the UK, Hungary and Italy) and the US and Australia: an individual adult was more likely to have both a surviving child and a surviving parent in the US than in any of the five European countries considered (Farkas and Hogan 1995). This finding was later confirmed for 


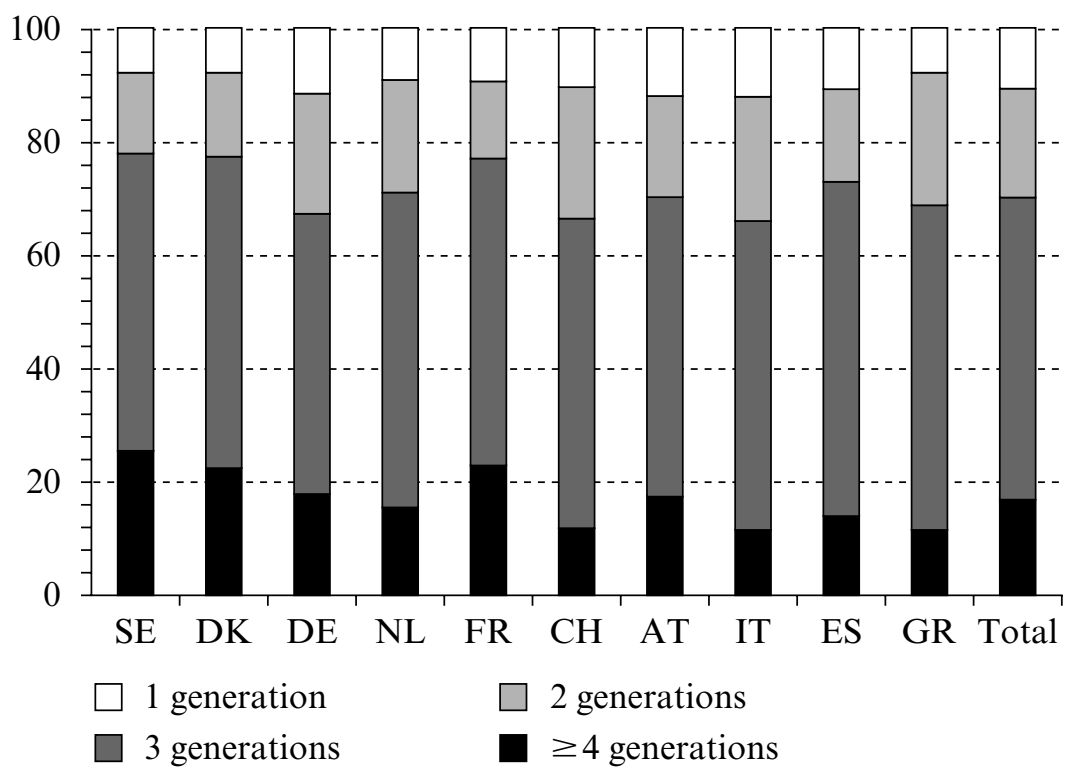

Note: SE: Sweden; DK: Denmark; DE: Germany; NL: Netherlands; FR: France; CH: Switzerland; AT: Austria; IT: Italy; ES: Spain and GR: Greece.

Source: Börsch-Supan et al. (2005).

\section{Figure I.1 Multigenerational families in 11 European countries}

the UK by Grundy (1999). A study of contemporary grandchildhood in Germany and Italy (Keck and Saraceno 2008), taking the perspective of the young generation, found that, although the chances of having a living grandparent are similar and fairly universal in the two countries both among young children and the under-35s in general, the number of living grandparents available to grandchildren is lower in Germany than in Italy due to the different impact the two World Wars had on men's chances of survival. Demographic processes linked to fertility and mortality are, in fact, not all that is responsible for the changes in the shape and size of intergenerational chains: wars and migration flows in the past and present centuries are also powerful causes of change.

Two further reflections are evoked by these findings. In the first place, the incidence of multigenerational families, and the size of each generation within them, may differ depending on the generation that is taken as the focal one (Hagestad 2006). The incidence of multigenerational families may be higher when considering older people than when considering children. The families of older people, in fact, by definition contain only those who 
have survived to become, at least theoretically, grandparents or greatgrandparents; the families of children also include children whose grandparents, and even more so great-grandparents, have died. In the second place, and for the same reason, even in ageing societies, families are not permanently three- and even less so four-generational. From both an individual and a family life-course perspective, the presence of three and, particularly, four generations occurs in specific phases of the individual and family life course. Most individuals and families experience the threegeneration phase one or two times over the life course (once when a child or a young family, once when old), and also for some length of time; a much smaller number of individuals and families experience a short fourgeneration phase. But at any point in time, three-generation families account for less than half of all families, while four-generation (or more) families account for only a very small percentage of all families. According to Farkas and Hogan's (1995) estimates for seven countries, the latter accounted for less than 3 per cent of all families in the mid-1990s, considering the situation of all age groups and not only that of those who are well into mature or old age.

The real novelty, therefore, appears to be the semi-universality and duration of grandchildhood. Attias-Donfut and Segalen (2001) have suggestively defined the twentieth century as the Siècle de grands-parents. Yet, we might also speak of the century in which grandchildhood has become a virtually universal role and a relatively long life stage, while the actual number of grandchildren has shrunk drastically. More parents are living to become grandparents of fewer grandchildren. But this also means that, on the one hand, the majority of children have the possibility of growing up with all or most of their grandparents alive; on the other hand, this is an experience that they share with few, if any, other children in their family network. In this perspective, it is somewhat puzzling that a large deal of research on intergenerational relationships in ageing societies and on kinships is still focused only on the parent-adult child relationship, overlooking the threegenerational dimension, that is, what Gunhild Hagestad in her chapter calls the book-ends generations. It is true that the relationship between grandparents and grandchildren is strongly mediated by the middle generation of those who are both children of the former and parents of the latter. But it cannot be reduced to this mediation and should be analysed on its own. Furthermore, it cannot be reduced simply to the issue of grandparents caring for their grandchildren when they are little. The presence of grandparents in principle offers opportunities for transmission and sharing across a long time span. In societies where everything seems focused on the present, the presence of the elderly within families offers a longer time perspective to the young, while relationships with the young may offer the old the opportunity to keep in touch with social change. 


\section{AN EXTENDED DURATION AND COMBINATION OF GENERATIONAL ROLES}

One of the reasons why much research focuses on the two-generational relationship between adult children and their parents is that the duration of both the parental and the child role has lengthened substantially. In principle, this relationship may last for over sixty years. For these two generations one might speak of a process and experience of co-ageing, in so far as they spend many years during which they both are, and grow, old. All generational roles may be understood as veritable careers in Elder's (1985) definition, with their phases and turning points. But those of child and parent are the longest and therefore those that are more open to strong differentiation over the life course.

The prolongation of roles occurs in both generations, but its impact on the overall balance of emotional investments, feelings of loyalty and practical obligations is probably higher for the children than for the parents. As children and parents age, after a period in which there may be a lightening of the burden of intergenerational obligations for both generations, these obligations may later increase over a long period of time - longer for the children than it had been for parents. Middle-aged children of elderly parents may at the same time be parents of young adults who are starting their own families and grandparents of grandchildren. If their parents become dependent, adult children's emotional attachments, feelings of loyalty and perceived moral obligations along the generational line may enter some kind of tension, if not contradiction, at the very moment in which they are called upon to redefine the child's role into one more similar to a parental, caring role. This is not only a practical shift. It may also involve the breaking down of boundaries of intimacy that are deeply entrenched in intergenerational roles, and more generally may entail a symbolic realignment of memories and emotional biographies. While in the past the main turning points for a child included leaving the parental household and then becoming a parent, now there is this additional passage of becoming, to a greater or lesser degree, a semi-parental figure for one's own parents. The present cohort of 50-60 year olds is the first to experience this transition as an almost normative passage in the life course.

This lengthening and transformation of generational roles de facto also becomes a learning environment for the younger generation, and the impact of this has not yet been studied. Children learn that families involve more than a two-generational relationship and, in fact, include a complex generational stratification that may span almost a century of relationships and - sometimes contested - memories. These long chains of living 
generations may help bridge differences in experiences at the private and collective level caused by long intergenerational spacing. Since generations have a long 'common time', in fact, cultural changes do not happen only in one generation; they involve all co-living generations and are also mediated by communication between and interest in each other across generations. In this perspective, patterns of proximity between generations might offer an important - and differentiated - context for mutual socialisation across generations. Grandchildren living close to grandparents and interacting frequently with them may grow up in a somewhat different socialisation context than those who do not have grandparents, or have only very sporadic contact with them. And elderly people without grandchildren or grandnieces or -nephews may feel more estranged from the younger generation and cohorts.

On the other hand, through their parents' experience, children see that the child role and generational position is seemingly a never-ending one. This experience interacts with their own as children in a historical period in which, for different reasons - lengthy education, growing labour market insecurity, overall delay in traversing all the passages that once marked entrance in adulthood - children remain dependent on their families for longer and delay setting up their own households, therefore also maintaining for longer periods the status of somewhat dependent child, in what has been called an extended, or post-, adolescence. How those who are now in the position of prolonged social (not fully autonomous) childhood - while also witnessing their parents' experience of demographically long childhood - view their future in the continuation of the generational chain, and whether their experience will affect their decisions as to whether to have their own children or not, remains to be explored. Some data - such as cross-country differences in leaving the parental home and having one's first child - however, suggest that where welfare-state arrangements lighten the burden of long family dependencies for the young, they are more willing to set up their own households and to enter the parental role than in countries where family dependencies are more exclusive and last longer.

\section{SUPPORT AND TRANSFERS BETWEEN GENERATIONS}

A large share of the studies on intergenerational relations within families, including those in this volume, focus on patterns of solidarity and therefore on various forms of support. Support and solidarity, however, are far from being univocal concepts. In the so-called theory of intergenerational 
solidarity (see, e.g., Bengtson 2001; Bengtson and Roberts 1991), which has had an important influence in intergenerational studies, solidarity is a broad concept that has both emotional and cognitive dimensions. The chapter by Anja Steinbach and Johannes Kopp, focused on Germany, continues this rich tradition, exploring the different dimensions of intergenerational relations. Many authors, however, including many in this book, adopt a more circumscribed notion of support and distinguish between contacts and support, restricting the latter to practical (financial or other) help that is either given or received. The focus on solidarity and support, whatever the definition used, and even the conceptual limitation of a perspective that frames all intergenerational exchanges in the language of support, has the merit of documenting how intergenerational relations within families also maintain an important solidaristic role in increasingly individualised and welfare-state societies.

All studies indicate that financial transfers flow downwards from the older to the younger generations through inheritance, but also through gifts and inter vivos transfers (Attias-Donfut and Wolff 2000a, 2000b; Albertini et al. 2007). This downward direction is also apparent in countries - such as the US and the UK - that do not have specific norms concerning inheritance (Finch 2004; Kohli 1999, 2004). A prevalence of upward (from the middle generation) financial transfers is found only in countries with high levels of poverty among the elderly and weak pension systems that do not offer adequate universal coverage, or among social groups, particularly migrants from developing countries, in which the elderly have little access to resources of their own. The chapters by Claudine Attias-Donfut and François-Charles Wolff, Helen BaykaraKrumme, and Ulla Björnberg and Hans Ekbrand on natives and immigrants in France, Germany and Sweden, respectively, illustrate this. Care/time transfers, by contrast, flow both downwards (from parents to children and grandchildren) and upwards (from mature adult children to frail elderly parents). For this reason, the middle generation, particularly in the case of women, is sometimes called the sandwich generation, caught between the dual demands of support (mostly care ) coming from above and from below (e.g., Grundy and Henretta 2006). At the comparative level, the pattern seems to have a north-south gradient (e.g., Ogg and Renaut 2005), with more people providing support in the northern countries than in the southern ones. But the gradient is the opposite when frequency is considered, with many more helpers providing help regularly and frequently in the southern countries than in the northern ones. This finding confirms the criticism levied by some authors (see, e.g., AttiasDonfut and Wolff 2000b; Attias-Donfut et al. 2005; Knijn and Komter 2004; Kohli 1999; Künemund and Rein 1999) against the so-called 
crowding-out hypothesis, according to which generous welfare states crowd out private intergenerational solidarity. It is less clear whether the findings support the opposite hypothesis of 'crowding in', in so far that in the more generous welfare states private intergenerational solidarity is more diffuse, but less intense. What emerges clearly is that where private intergenerational solidarity is more exclusive and more necessary, generations within families are more dependent on each other, which delays the financial autonomy of the young and even their ability to form their own families (Albertini 2007; Dalla Zuanna 2001; Saraceno 2004), but also renders the frail elderly heavily dependent on the care of their adult children/daughters (Sarasa and Mestres 2007).

The role played by intergenerational solidarity in addressing the needs of adult children is the focus of two chapters in this book. Martin Kohli and Marco Albertini, on the basis of SHARE data, analyse the impact of life 'crises' (parenthood and loss of a partner) in children's life on parental support in four countries characterised by different welfare and family arrangements. By considering the overall support 'package' parents may provide to individual children, they find not only that type of need matters, but that mode, rather than intensity, of parental support changes across countries. Teresio Poggio, focusing on access to housing, shows how the intergenerational reproduction of home ownership is a specific pattern of intergenerational interdependence in the Mediterranean welfare states, involving long-term support expectations and exchanges between generations.

Three chapters in this book address specifically the crowding out/ crowding in debate from different perspectives. Harald Künemund discusses critically the conceptual and theoretical assumptions behind the two opposing crowding-out/crowding-in hypotheses, the empirical evidence available in support of each of them, the research strategies employed so far and those which would be further necessary in order to fully test them. The other two chapters are based on the SHARE comparative data set. Sebastian Sarasa and Sunnee Billingsley focus on the interplay between social stratification, social norms, including gender norms, and welfare regime in affecting the amount of family care provided by adult children to their frail elderly parents. Wolfgang Keck analyses whether recourse to forms of publicly provided care affects the relationship between the frail elderly and their adult children when the latter do not provide care. He finds that relationships are negatively affected not when there is provision by services, but when there is provision by a sibling of a non-caring child, suggesting that in this case there is the feeling that some norm of justice and fairness is broken.

The direction of transfers may be similar across countries and most social groups, but the reasons for giving may differ, depending on the norms 
and expectations governing both who, within a family, should give what, and who, within a family, deserves what kind of support (Finch and Mason 1993; Finch 2004; Kohli and Künemund 2003). The chapter by Ulla Björnberg and Hans Ekbrand on Sweden explores precisely the different moral logics guiding intergenerational support within various groups in that country. In the same vein, particularly in the case of care for frail elderly parents, studies have shown that normative values and feelings of affection and reciprocity, although mutually reinforcing, do not belong to the same logic nor act at the same level. Care might be provided out of a feeling of normative obligation even in cases where affection is lacking and individual relationships are bad (e.g., Walker 1993). A comparative study (Lowenstein and Daatland 2006) found that norms are more prescriptive in the southern European countries than in the northern ones. In the latter countries, intergenerational exchanges appear more open to negotiation. The relevance of (socially structured) normative values and their different weights in motivating behaviour once again indicate that intergenerational relationships are not shaped only by individual and family-level factors (e.g., the quality and the history of the relationship), but also by social determinants. This also helps to explain gender differences in the provision and receipt of support.

\section{INTERGENERATIONAL RELATIONS IN THE CONTEXT OF CHANGING FAMILY FORMS}

The debate around the crowding-in as opposed to the crowding-out hypothesis and the possible impact on the intergenerational transmission of inequality concerns the micro-macro link between private and public intergenerational contracts. But the private intergenerational contract may also be affected by changes at the micro level, for example, in the patterns of family formation.

While increasing life expectancy offers the opportunity for unprecedented marriage durations, other social and cultural forces have substantially weakened marriages. Marital instability and cohabitation without marriage concur in reducing the role of marriage not only as the normal form of adult living, but also as a means of connecting generations. Does this affect the strength of intergenerational relationships themselves?

In the case of marriage instability, the answer is twofold, depending on the generational perspective. Children, particularly daughters, who divorce can often count on their parents' and siblings' support (Dykstra 1997; Kohli 1999; Attias-Donfut and Wolff 2000a; Kohli and Albertini this volume). On the contrary, in all countries divorce has a negative 
impact on long-term intergenerational relationships, affecting not only the parent-child relationship but also, as a consequence, the grandparentgrandchild bond (Dykstra 1997). As the comparative chapter by Matthijs Kalmijn and the mainly Italy-focused chapter by Marco Albertini and Chiara Saraceno show, the phenomenon is, however, strongly skewed: it is the father-child relationship, and therefore the paternal intergenerational chain, that is most negatively affected, while the maternal line is not or is only weakly affected - due not only to the gender division of parenting responsibilities but to the legal and practical patterns of child custody that were prevalent in all countries in the recent past and are still prevalent in many of them. Divorced fathers, therefore, risk remaining isolated and without family support in older age more than do both widowed fathers and divorced and widowed mothers. And children whose grandparents have divorced risk having fewer contacts with them than children whose grandparents have remained married to each other. We have to wait until a generation of children who have experienced joint custody have grown up and formed their own families to see whether this asymmetrical weakening will change and, if so, in what direction. What is clear is that, at least until now, the couple's relationship is still the main factor connecting generations - mostly through the kin work of women.

But does this connecting role work in the same way for marriage and for cohabitation without marriage? Here the research data are less systematic and rich than those concerning the impact of divorce. They also offer less straightforward evidence, first of all because they rarely distinguish between different forms of cohabitation (Harper 2004; Kiernan 2000), particularly between those entered as a temporary relationship and those entered as a form of stable life alternative to marriage. This lack of distinction results in an over-representation of cohabitation as more prone to dissolution than marriage, therefore involving all the negative consequences for intergenerational relationships of marital instability.

Divorce and couple separation, like widowhood, open the possibility of forming a new couple, therefore in theory offering children (and adults) forms of intergenerational relationships other than those based on blood. There may be step-grandparents and grandchildren, step-aunts/uncles and step-nieces/nephews. Some studies have started to explore to what degree step-families create their own intergenerational chains (e.g., Bornat et al. 1999). The results are not yet fully conclusive, although they seem to indicate that blood ties tend to prevail. Moreover, some studies on the impact of remarriage indicate that re-partnering, instead of enlarging the possibilities for intergenerational relationships beyond the mediation of blood ties, actually risks weakening blood-based relationships (e.g., Albertini and Saraceno this volume; De Jong Gierveld and Peeters 2003). Both remarried 
mothers and remarried fathers in fact have fewer contacts than married and widowed parents with their adult children, and therefore also with their grandchildren.

Theo van Tilburg and Suzan van der Pas in their chapter in this book offer a complex forecast of the impact of family changes on the persistence of intergenerational relationships from the perspective of the Dutch context. While in the short term these relationships seem to remain strong, taking a longer view they appear more vulnerable to childlessness, marriage instability, increasing cohabitation without marriage and so forth.

The persisting prevalence of vertical blood ties in shaping intergenerational relationships in families leads to some concern with regard to the growing group of the childless, particularly when they become old and frail (e.g. Bengtson and Achenbaum 1993). Studies of the childless elderly are just being developed in intergenerational relationship research (see the two 2007 issues of the Journal of Family Issues devoted to this topic). Childless people may maintain more systematic bonds with the extended family, both horizontally and vertically, and even develop some kind of fictive kin relationships with friends. The shrinking of kinship, however, due to the decline in fertility, might render these options less available in the future particularly the possibility of bonds with extended kin. The present middleaged childless have fewer siblings than their parents and also fewer nephews and nieces. Whether this shrinking of kinship may be replaced by elective kinship remains a question to be explored, although in general men appear more vulnerable than women to the risk of isolation due to childlessness (Dykstra and Hagestad 2007). They might, therefore, be the first beneficiaries of policies aiming at integrating age groups, and particularly the young and the old, such as those advocated by Hagestad in the conclusion of her chapter.

\section{CONCLUSION}

Two partly overlapping debates are driving contemporary research on intergenerational relationships in families. One concerns the relationship between public and private intergenerational contracts and particularly the impact of welfare-state arrangements on intergenerational solidarity within families. The other concerns the impact of both ageing and changing family forms on the quality and intensity of intergenerational relationships within the family. The first debate may be synthesised as that between the crowding-out versus the crowding-in hypothesis. Most studies seem to support the latter rather than the former phenomenon, citing evidence that relationships remain strong. The second debate seems more open. 
While there is ample evidence of the negative impact of marital instability, even in countries where divorce has been widespread and common for over two generations, other aspects of family change, such as cohabitation instead of marriage, homosexual families and childlessness, require further exploration.

These two debates have developed mostly from within research focusing either on country-specific or comparative cross-country data. Migration and international mobility, however, are reshuffling country boundaries in many ways, including those concerning patterns of family formation, family culture and intergenerational relations. Whether family patterns are becoming increasingly similar across Europe, as Segalen (1997) and Murphy (2004) argue, or the longstanding differences are persisting, as Reher (1998) maintains, is still an open question. But Europeans cross borders and so - even more so - do migrants from non-European countries. They take with them their specific family cultures but, at the same time, by the very act of moving, they disrupt at least partly the very conditions that supported those cultures and the resulting expectations. Furthermore, as paid care workers, migrants sometime substitute both welfare state and kinship care work within the host countries, thus interfering with local intergenerational relationships at the societal and family level. As mentioned above, three chapters in this book look specifically at how intergenerational relationships are affected by migration and how they compare to those prevalent in the host country. Taken together, they offer a threefold comparative perspective: between migrants and natives, between different groups of migrants, and between different migratory contexts. All three of these studies show the strong resilience of intergenerational relations even when distance and economic difficulty put them under great strain. They also show that the (economic, but also cultural) constraints under which these relationships occur may present - particularly for the poorer groups and those who have greater responsibilities towards those left behind specific risks of widening inequalities in the younger generations. More studies, as well as differentiated research strategies, are needed to further monitor how these trends differ across migrant groups and migratory circumstances, to examine whether welfare regimes play a role, and to see what happens among second- and third-generation migrants.

Depending on the perspective one takes, intergenerational relationships today seem to represent a new form of stability in an otherwise very dynamic and changing family, or a relationship dependent on precarious circumstances. This precariousness is to a large extent the consequence of individual choices. But social policies also play an important role, not because they may act as a substitute for missing or ruptured ties, but because they can make them more or less viable. 


\section{NOTES}

1. Although the terms generation and intergenerational relationships are often applied both to family and societal positions, they should ideally be reserved for the former, given that these refer to positions in a lineage, while the latter concern relationships between age groups that are mediated by institutions (see, e.g., Bengtson and Cutler 1976; Leisering 1992). In the same vein, Pilcher (1994) suggests distinguishing between family generations and societal generations.

2. A similar, and probably even more dramatic, change in the shape of the intergenerational kinship structure is occurring in the former communist countries, which went in a few years from having a fertility rate that was on average higher than that of most Western European countries to a fertility rate that is lower than the Italian one. In these countries, however, life expectancy also fell in many instances. There has therefore been a simultaneous and dramatic reduction of all generations.

\section{REFERENCES}

Achenbaum, Andrew W. (2004), 'One happy family? Sources of intergenerational solidarity and tension as contemporary US ages', in S. Harper (ed.), Families in Ageing Societies. A Multi-Disciplinary Approach, Oxford: Oxford University Press, pp. 53-63.

Alber, Jens and Ulrich Kohler (2004), Health and Care in an Enlarged Europe, Dublin: European Foundation for the Improvement of Living and Working Conditions. Quality of Life in Europe.

Albertini, Marco (2007), 'Il contratto generazionale e la disuguaglianza in Italia. Un conflitto tra le generazioni?', paper presented at the conference 'Esplorare la coesione sociale: teorie, ipotesi, modelli, tecniche di analisi dei dati', Italian Sociological Association, Trento, Facoltà di Sociologia, 28-30 June.

Albertini, M., M. Kohli and C. Vogel (2007), 'Intergenerational transfers of time and money in European families: common patterns - different regimes?', Journal of European Social Policy, 17, 319-34.

Arber, Sara and Claudine Attias-Donfut (eds) (2000), The Myth of Generational Conflict, London and New York: Routledge.

Attias-Donfut, Claudine and François-Charles Wolff (2000a), 'The redistributive effects of generational transfers', in S. Arber and C. Attias-Donfut (eds), The Myth of Generational Conflict, London and New York: Routledge, pp. 22-46.

Attias-Donfut, Claudine and François-Charles Wolff (2000b), 'Complementarity between private and public transfers', in S. Arber and C. Attias-Donfut (eds), The Myth of Generational Conflict, London and New York: Routledge, pp. 47-68.

Attias-Donfut, Claudine and Martine Segalen (eds) (2001), Le Siècle de Grandsparents, Paris: Editions Autrement.

Attias-Donfut, C., J. Ogg and F.-C. Wolff (2005), 'European patterns of intergenerational transfers', European Journal of Ageing, 2, 161-73.

Bengtson, V.L. (2001), 'Beyond the nuclear family: the increasing importance of multigenerational bonds', Journal of Marriage and the Family, 63, 1-15.

Bengtson, Vern L. and Andrew W. Achenbaum (eds) (1993), The Changing Contract across Generations, New York: Aldine de Gruyter.

Bengtson, Vern L. and Neal E. Cutler (1976), 'Generations and intergenerational relations: perspectives on age groups and social change', in R.H. Binstock and 
Ethel Shanas (eds), Handbook on Aging and the Social Sciences, New York: Van Nostrand Reinhold, pp. 130-59.

Bengtson, V.L. and R.E.L. Roberts (1991), 'Intergenerational solidarity in aging families: an example of formal theory construction', Journal of Marriage and the Family, 53, 856-70.

Bertram, Hans (2000), 'Die verborgenen familiären Beziehungen in Deutschland: die multilokale Mehrgenerationenfamilie', in M. Kohli and M. Szydlik (eds), Generationen in Familie und Gesellschaft, Leske and Budrich: Opladen, pp. 97-121.

Binstock, Robert H. and Jill Guadagno (2001), 'Aging and politics', in Robert H. Binstock and Linda K. George (eds), Handbook of Aging and the Social Sciences, San Diego, CA: Academic Press.

Bornat, J., B. Dimmock, D. Jones and S. Peace (1999), 'Step-families and older people: evaluating the implications of family change for an elderly population', Ageing and Society, 19, 239-61.

Börsch-Supan, Axel, Agar Brugiavini, Hendrik Jürges, Johan Mackenbach, Johannes Siegrist and Guglielmo Weber (eds) (2005), Health, Ageing and Retirement in Europe: First Results From the Survey of Health, Ageing and Retirement in Europe, Mannheim: Mannheim Research Institute for the Economics of Aging (MEA).

Brady, D. (2004), 'Reconsidering the divergence between elderly, child and overall poverty', Luxembourg Income Study Working Paper Series, no. 371.

Coleman, David (2005), 'Facing the 21st century: new developments, continuing problems', in Miroslav Macura, Alphonse L. MacDonald and Werner Haug (eds), The New Demographic Regime. Population Challenges and Policy Responses, Geneva: United Nations, pp. 11-44.

Dalla Zuanna, G. (2001), 'The banquet of Aeolus. A familistic interpretation of Italy's lowest low fertility', in Demographic Research, 4 (5), 133-62.

De Jong Gierveld, J. and A. Peeters (2003), 'The interweaving of repartnered older adults' lives with their children and siblings', Ageing and Society, 23, 187-205.

Dykstra, P.A. (1997), 'The effects of divorce on intergenerational exchanges in families', The Netherlands Journal of Social Sciences, 33 (2), 77-93.

Dykstra, P.A. and G. Hagestad (2007), 'Childlessness and parenthood in two centuries: different roads, different maps?', Journal of Family Issues, 28 (11), 1518-32.

Elder, Glen Jr (ed.) (1985), Life Course Dynamics: Trajectories and Transitions, 1968-1980, Ithaca, NY: Cornell University Press.

Esping-Andersen, G. and S. Sarasa (2002), 'The generational contract reconsidered', Journal of European Social Policy, 12, 5-21.

European Data Service (2007), 'Eurostat online database', www.edsdestatis.de/de/database/estatonline.php (accessed 21 March 2007).

Farkas, Janis I. and Dennis P. Hogan (1995), 'The demography of changing intergenerational relationships', in Vern Bengtson, K. Schaie and L. Burton (eds), Adult Intergenerational Relations, New York: Springer, pp. 1-8.

Ferrera, M. (1996), 'Il modello sud-Europeo di welfare state', Rivista Italiana di Scienza Politica, 26 (1), 67-101.

Finch, J. (2004), 'Inheritance and intergenerational relationships in English families', in S. Harper (ed.), Families in Ageing Societies. A Multi-Disciplinary Approach, Oxford: Oxford University Press, pp. 164-75.

Finch, Janet and Jennifer Mason (1993), Negotiating Family Responsibilities, London: Routledge. 
Flora, Peter, Franz Kraus and Winfried Pfenning (1987), State, Economy, and Society in Western Europe 1815-1975, Frankfurt: Campus.

Grundy, Emily (1999), 'Household and family change in mid and later life in England and Wales', in Susan McRae (ed.), Changing Britain: Families and Households in the 1990s, Oxford: Oxford University Press, pp. 201-28.

Grundy, E. and J.C. Henretta (2006), 'Between elderly parents and adult children: a new look at the intergenerational care provided by the "sandwich generation", Ageing and Society, 26, 707-22.

Hagestad, G. (2006), 'Transfers between grandparents and grandchildren: the importance of taking a three-generation perspective', Zeitschrift für Familienforschung, 3, 315-32.

Harper, Sarah (2004), 'The challenge for families of demographic ageing', in S. Harper (ed.), Families in Ageing Societies. A Multi-Disciplinary Approach, Oxford: Oxford University Press, pp. 6-30.

Harper, Sarah (ed.) (2004), Families in Ageing Societies. A Multi-Disciplinary Approach, Oxford: Oxford University Press.

Journal of Family Issues (2007), two special issues on 'Multiple meanings of childlessness in late life - findings for seven societies', 28 (10,11).

Keck, Wolfgang and Chiara Saraceno (2008), 'Grandchildhood in Germany and Italy. An exploration', in Arnlaug Leira and Chiara Saraceno (eds), Childhood: Changing Contexts, Comparative Social Research, Vol. 25, Biggleswade: Emerald, pp. 135-66.

Kiernan, Kathleen E. (2000), 'European perspectives on union formation', in Linda G. Waite, Christine Bachrach, Michelle Hindin, Elizabeth Thompson and Arland Thorton (eds), Ties That Bind: Perspectives on Marriage and Cohabitation, New York: Aldine de Gruyter, pp. 40-58.

Knijn, Trudie and Aafke Komter (eds) (2004), Solidarity Between the Sexes and the Generations: Transformations in Europe, Cheltenham, UK and Northampton, MA, USA: Edward Elgar.

Kohli, M. (1999), 'Private and public transfers between generations', European Societies, 1 (1), 103-22.

Kohli, Martin (2004), 'Intergenerational transfers and inheritance: a comparative view', in Merril Silverstein (ed.), Intergenerational Relations Across Time and Place, New York: Springer, pp. 266-89.

Kohli, Martin and Harald Künemund (2003), 'Intergenerational transfers in the family: what motives for giving?', in Vern L. Bengtson and A. Lowenstein (eds), Global Ageing and Challenges to Families, New York: Aldine de Gruyter, pp. 123-42.

Künemund, H. and M. Rein (1999), 'There is more to receiving than needing: theoretical arguments and empirical explorations of crowding in and crowding out', Ageing and Society, 19, 93-121.

Künemund, H., A. Motel-Klingebiel and M. Kohli (2005), 'Do intergenerational transfers from elderly parents increase social inequality among their middle-aged children? Evidence from the German Aging Survey', Journals of Gerontology Series B: Psychological Sciences and Social Sciences, 60, 30-36.

Leisering, Lutz (1992), Sozialstaat und demografischer Wandel, Frankfurt and New York: Campus.

Lowenstein, A. and S.O. Daatland (2006), 'Filial norms and family support in a comparative cross-national context: evidence from the OASIS study', Ageing and Society, 26, 203-23. 
Millar, Jane and Andrea Warman (1996), Family Obligations in Europe, London: Family Policy Studies Centre.

Murphy, Mike (2004), 'Models of kinship from the developed world', in S. Harper (ed.), Families in Ageing Societies. A Multi-Disciplinary Approach, Oxford: Oxford University Press, pp. 31-52.

Ogg, J. and S. Renaut (2005), 'Le soutien familial intergénérationnel dans l'Europe élargie', Retraite et société, 46, 30-59.

Pilcher, J. (1994), 'Mannheim's sociology of generations: an undervalued legacy', British Journal of Sociology, 45 (3), 481-95.

Pitrou, A. (1977), 'Le soutien familial dans la société urbaine', in Revue Française de Sociologie, XVIII, 45-84.

Reher, S.D. (1998), 'Family ties in Western Europe: persistent contrast', Population and Development Review, 24 (2), 203-34.

Saraceno, Chiara (2004), 'The reproductive paradox of "weak" and "strong" families in contemporary Europe', in Hartmut Kaelble and Gunther Schmid (eds), Das europäische Sozialmodell, WZB-Jahrbuch, Berlin: Edition Sigma, pp.347-74.

Sarasa, S. and J. Mestres (2007), 'Women's employment and the adult caring burden', in Gosta Esping Andersen (ed.), Family Formation and Family Dilemmas in Contemporary Europe, Bilbao: Fondacion Bova, pp. 185-222.

Segalen, Martine (1997), 'Introduction', in Marianne Gullestad and Martine Segalen (eds), Family and Kinship in Europe, London: Pinter, pp. 1-13.

Sussman, M.B. and L. Burchinal (1962), 'Kin-family networks', in Marriage and Family Living, XXIV, 231-40.

Walker, Alan (1993), 'Intergenerational relations and welfare restructuring: the social construction of an intergenerational problem', in Vern Bengtson and Andrew W. Achenbaum (eds), The Changing Contract Across Generations, New York: Aldine de Gruyter, pp. 141-65.

Willmott, Peter and Michael Young (1964), Family and Kinship in East London, London: Routledge and Kegan Paul. 